\title{
8
}

\section{Broken Promise Men: The Malevolent Absence of the State at the McArthur River Mine, Northern Territory}

\author{
Gareth Lewis
}

\begin{abstract}
The open-cut is right in the place where the Rainbow Serpent rests. They cut open not just the snake, but us ceremony people too. They pushed us aside just like they did first time when they invaded our Countries with their guns and poison to take our land.
\end{abstract}

Jacky Green (Green et al. 2017)

\section{Introduction}

The McArthur River in the southeast of Australia's Northern Territory flows from its source in the dry Barkly tablelands $520 \mathrm{~km}$ northwards to the tropical southwestern Gulf of Carpentaria where it meets the ocean near the Sir Edward Pellew group of islands. The township of Borroloola is situated on its western bank, $45 \mathrm{~km}$ upstream from the coast. The McArthur is a river which has economically and spiritually sustained countless generations of Aboriginal peoples including, for its middle and lower reaches, the Gurdanji and Yanyuwa along with their Mara and Garrwa neighbours. Replete with food and utilitarian resources, a means of travel, trade and communication, the river's importance is 
reflected in its central place in an associative cultural landscape, being the foci for many narratives, ceremonies, songs and sites of spiritual and sacred significance for Aboriginal people across the Gulf region.

For recent generations, the river has been transformed. Following European arrival into the region in the second half of the nineteenth century, Aboriginal people have experienced massive upheavals from violence, disease, dislocation from and usurpation of their traditional lands, and the devastating host of health, social and cultural impacts wrought by towns, pastoral stations and mining development. At the time of European 'settlement' the McArthur River flowed with the blood of the Gulf country's Aboriginal peoples, massacred at the hands of European police and 'settlers'. Currently it flows with contamination from the McArthur River Mine located some $50 \mathrm{~km}$ upstream from Borroloola. Throughout this period the state in its various guises has played a critical role, usually from afar, in shaping the policies and practices of non-Indigenous people towards and regarding Aboriginal people in the Gulf region.

This chapter examines the role of the state as both sponsor and regulator of resource extraction in this region. I explore recent Aboriginal perspectives of the McArthur River Mine, its operator Glencore, and by default the state, who together have dominated and disrupted the local and regional Aboriginal world and literally reshaped Aboriginal people's connections to their traditional lands and waters. Reflecting on the Indigenous historical experience and memory of state-sanctioned violence and dispossession in the region, I conclude that the state emerges as a consistently malevolent absence in Aboriginal peoples' lives, bridging past violence with current environmental, social and cultural impacts of the state-sanctioned—yet questionably assessed and monitored-resource extraction activities at the McArthur River Mine.

I review the history of the development of the McArthur River Mine against a backdrop of shifting Australian Indigenous policy and mining company practices, then apply Sawyer and Gomez's (2008) work on transnational governmentality and resource extraction, and Owen and Kemp's (2017) work on social licence and countervailing power in the global mining industry, to explore the interplay of the state and mining company throughout. From recent Aboriginal voices expressed in word, song and imagery I conclude that the Aboriginal peoples of the Gulf have been brutalised as colonial subjects and are now disempowered as 'extractive subjects' (Fredericksen and Himley 2019: 59) through the actions of a malevolently absent state. 


\section{The Malevolent Absence of the Colonial State}

From the 1870s the first wave of sustained European economic and physical presence in Gulf Country of the Northern Territory commenced with the rapid expansion of the pastoral industry from north Queensland into the Gulf region and beyond. Aboriginal inhabitants of the Gulf country felt the full force of this pastoral expansion from the late $1800 \mathrm{~s}$ through to the early decades of the twentieth century. Referred to by Gulf Aboriginal peoples as the 'Wild Times', this was an era of rampant frontier violence with police, pastoralists and civilians taking to their guns against them with impunity. The contemporary Gulf Aboriginal perspective is simply put:

the government cleared us off our lands by shooting us and putting chains around our necks and dragging us off. (Kerins and Green 2016: 124)

Conditions were described in the 1887 Northern Territory Government Resident's Annual Report:

The whites look well to their Winchesters and revolvers, and usually proceed on the principle of being on the safe side. It is an affectation of ignorance to pretend not to know that this is the condition of things throughout the 'backblocks' and the 'new country' of Australia. (South Australia 1887: 17)

The politicians, their policy, and decision makers in government were well removed from the action in the corridors of power far away in Adelaide, which still administered the Northern Territory, or in the northern administrative outpost of Darwin. Extensive historical research into this frontier violence has been undertaken by Tony Roberts. Former public servant Brian Stacey notes Roberts' description of the enormity of the dispossession and violence that overwhelmed Aboriginal people in the short space of three decades between 1881 and 1910. He writes:

On the back of a pastoral boom engineered by the South Australian colony, more than 600 Aboriginal men, women, children and babies, or about one sixth of the population, were killed in the Gulf Country. 
In just four years ... the Aboriginal population of at least 4000, composed of 15 tribes or language groups, was dispossessed of every inch of land. (Stacey 2018: 13)

Stacey goes on to describe this practice as:

terra nullius applied in a savage, illegal and secret way in Australia’s last frontier by South Australia's colonial politicians. The evidence is there were dozens of massacres in the Gulf Country which South Australia's Attorneys-General and Premiers were alert to but refused to prevent, or to prosecute those responsible. (Stacey 2018: 13)

Robert's 2009 essay The Brutal Truth details the gruesome original records of state-endorsed and sponsored 'nigger hunts', dispersals, and 'picnics with the natives'. He notes the equipping of police and civilians in the Gulf Country with the latest powerful Martini-Henry rifles and unlimited ammunition:

Successive governments issued the police with unlimited ammunition and the authority to use it; they also issued arms to civilian punitive parties.

They kept sending the ammunition in massive quantities to the Territory, knowing it was being used for a single function: to shoot the blacks. They asked no questions, did no stocktakes, took no count of the dead ... There is evidence of at least 50 massacres in the Gulf Country of the Territory up to 1910. It is impossible to estimate how many more went unrecorded. (Roberts 2009)

On the McArthur River some $60 \mathrm{~km}$ upstream from the McArthur River Mine is Dunggunmini: a permanent waterhole which is a Gurdanji sacred place (see Figure 8.1). John Avery recorded a narrative of a massacre at this place from a land claim informant during 1977 :

There was a mob of Aboriginals camping here in the old times, poor buggers, when Top Station was up. Frank Meagan came out with pack horses, plant, trailing horses and rifles. They been hunting around for people to shoot. They left their horses north of the spring and swung around the spring. They into them and shot them all. They shot the whole mob. Some fellas got out, some got up the steep cliffs. The waterhole was all blood-girls and boys, old women and men were shot. They did the same all around right down to Kilgour and Amelia Spring. Frank Meagan also poisoned people at Warunguri. (Avery and McLaughlin 1977: 4) 


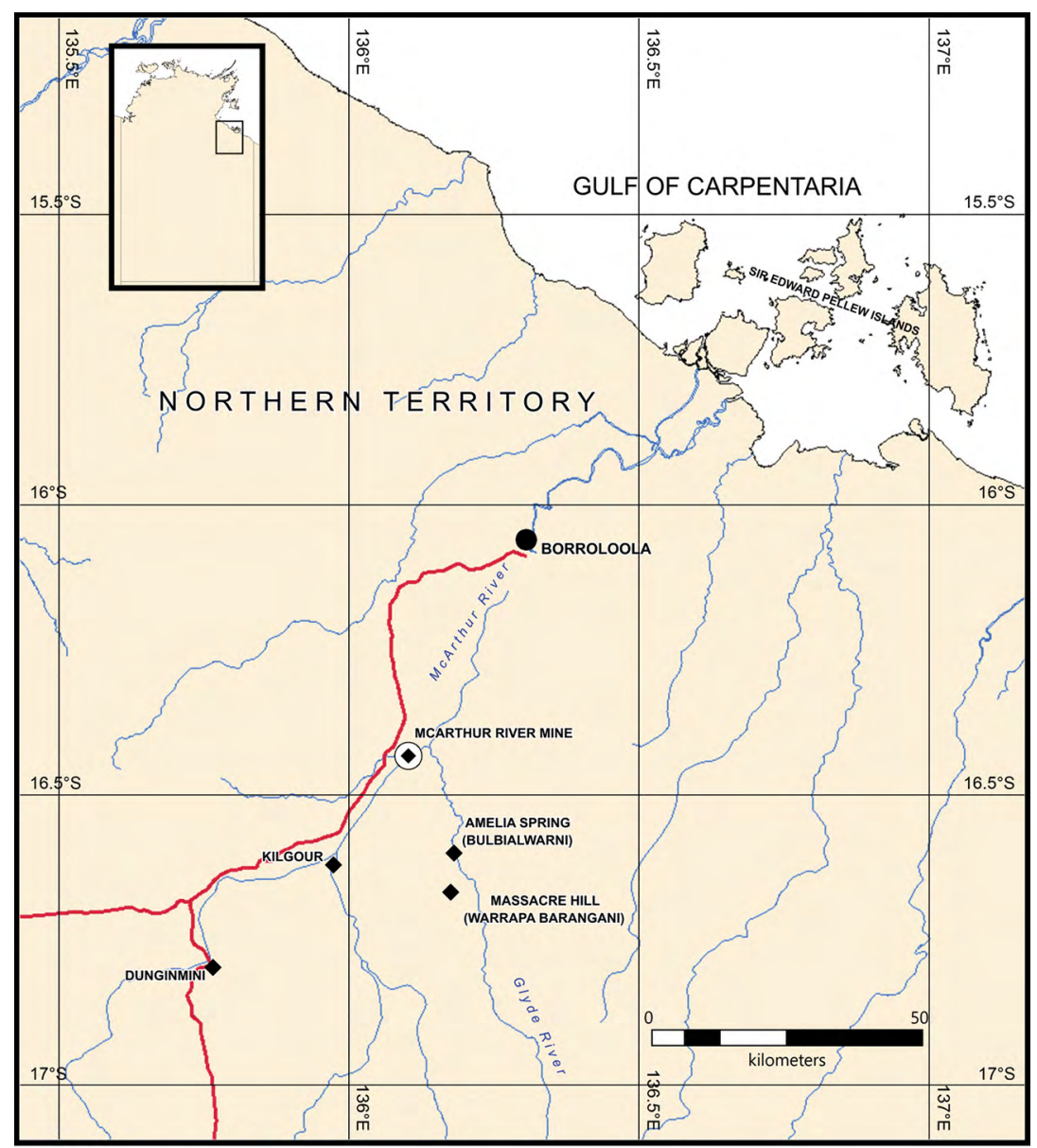

Figure 8.1 McArthur River Mine and surrounding region, Northern Territory

Source: Map by the author, background data supplied by the Department of Infrastructure, Planning and Logistics (C) Northern Territory Government

Kilgour is downstream again on the McArthur River closer to the mine. Amelia Springs is a site on the Glyde River where a rainbow snake travels northwards to meet its northern counterpart at the mine site. Nearby, upstream on Lamont Creek, a tributary of the Glyde, marked on the current topographic maps is Massacre Hill, unashamedly marking this rapid violent transformation of the local traditional geography and knowledge systems developed over countless generations by Aboriginal people. 
The historical records attest to the malevolent role the colonial state played in this violence. Administered from Adelaide by the South Australian Government, nearly 3,000 km away, up until 1911 and then by the Commonwealth Government even further away in Canberra, the physical distance of the state could not have been greater. Such physical distance combined with the lack of any administrative presence left the implementation of state policy on the frontiers in the hands of police, pastoralists and other civilians who were heavily armed by the state. It created the illusion of an absent state on the frontier when in actuality the state was embodied by those whom it armed. Andrew Lattas surmised similar processes in colonial New South Wales:

democracy makes every man an expression of reason ... and thus makes him part of the state. It was precisely in these terms that pastoralists on the frontier justified their use of violence, they saw themselves as an extension of the rational ordering effects of the state. They appropriated often the state's right to a monopoly of violence because they claimed to embody the principles of the state. (Lattas 1987: 50)

Such a 'democratisation of violence' during these Wild Times allowed the state to occupy with ambiguity the role of policy maker while, whenever convenient, feigning absence and ignorance of the violent implementation of their policies. Similar to Lattas' observations on the 'privatisation of the penal system', here we witness the 'privatisation of genocide' in the Gulf Country through a malevolent and feigned absence of the state. ${ }^{1}$

\section{McArthur River Mine and the Challenge of Land Rights}

The 'Here's Your Chance' deposit, one of the largest known sedimentary stratiform lead, zinc and silver deposits in the word, was identified by Mount Isa Mines geologists in 1955 on the McArthur River some $50 \mathrm{~km}$ upstream from Borroloola, on land traditionally owned by the Gurdanji (MRM 2018: 1.1). Surface mineralogy had been noted as early as 1887 at McArthur River station and lead outcrops in the area had been

1 Borrowing from Lattas' (1987: 56) descriptions of the privatisation of the penal system in colonial NSW, where convicts were being transferred to the control of pastoralists at the same time as police and pastoralists were carrying out a 'policy of genocide' against Aborigines. 
sporadically mined since around 1910, but the nature of the orebody identified in 1955 made the project unviable for any development until mining technology had sufficiently advanced in the 1990s. This time, between the identification of the orebody and its development in the early 1990s, saw the political landscape of Australia and the Northern Territory undergo massive changes especially in relation to the Indigenous policy arena.

During the 1960s the fight for equal wages for Aboriginal station workers culminated in Gurindji station workers going on strike during 1966 in what become known as the Wave Hill Walk-Off, and in 1963 the Yolngu people of northeast Arnhem Land delivered the Yirrkala Bark Petitions to the Commonwealth parliament in Canberra protesting the grant of mineral leases on land excised from the Arnhem Land Aboriginal reserve (Walker 2013: 33). In 1967 a national referendum determined that Indigenous people be included in the Australian census and that the Commonwealth be empowered to create laws for Indigenous people. By 1968 the sentiments expressed in the Yirrkala Bark Petitions escalated into legal action. The Gove Land Rights case heard in 1971, ${ }^{2}$ although unsuccessful, led to the Woodward Royal Commission inquiry into Aboriginal land rights in 1973-74 and the enactment by the Commonwealth of the Aboriginal Land Rights (Northern Territory) Act 1976 (ALRA), using its post-referendum powers. ${ }^{3}$

This growth of rights-based protests and legal action was reflected in a major shift in Australian Indigenous policy in the early 1970s, with Commonwealth-led self-determination policies replacing decades of assimilationism, which since the 1950s had sought to economically, culturally and physically centralise and integrate Indigenous peoples into the majority Australian mainstream society (Altman 2009: 21). A national Indigenous representative organisation, the Aboriginal and Torres Strait Islander Commission or ATSIC, was created and funded to administer Indigenous-specific programs, while arguably the high-water mark of self-determination policy, the ALRA, delivered the ability for Aboriginal

2 Milirpum and Others $v$ Nabalco and the Commonwealth of Australia.

3 There is abundant literature regarding the ALRA. For an early yet still relevant analysis of the principles of land rights as enacted in the Northern Territory see the introduction and relevant chapters in Peterson and Langton (1983). 
people in the Northern Territory to claim and win inalienable freehold title to their traditional lands and to control and negotiate benefits from any mining or other developments on such lands.

Mining companies seeking to explore and/or mine on granted Aboriginal freehold land were for the first time required to negotiate agreements with and obtain the consent of traditional Aboriginal owners before they could proceed. The ALRA established Land Councils as largely independent Commonwealth statutory bodies governed by elected Aboriginal community members (see Altman 2009: 22). ${ }^{4}$ These Land Councils administer the legislation, with the largest two, the Northern Land Council and the Central Land Council, employing considerable bureaucracies with professional legal, anthropological and technical staff. The ALRA also enabled the Northern Territory Government to set in place complementary legislation to protect Aboriginal scared sites in the Territory, which it did by enacting the Northern Territory Aboriginal Sacred Sites Act (NT Sacred Sites Act) soon after self-government was granted to the Northern Territory in 1978..$^{5}$ Although it was intended by the Whitlam Commonwealth Government as a model to be applied on a national scale, the idea of land rights never had any political chance of survival in the mineral-rich state of Western Australia (Altman 2009: 22).

In 1992 Mount Isa Mines announced its intention to commence underground mining at McArthur River and an environmental assessment process was undertaken. An initial 1993 Northern Territory Government approval for the mine signified the start of a series of approvals made by both the Commonwealth and Territory governments for the project and its subsequent expansions, aimed at securing the development and ensuring its longevity. These approvals were remarkable in that they sought to curtail potential and perceived threats of opposition to the mine posed by Aboriginal land rights, and the newly recognised native title rights.

To put this into further context: the early 1990s saw an electorally entrenched conservative Country Liberal Northern Territory Government vociferously opposed to land rights and desperate for an investment and economic development 'win' after the controversial Coronation Hill project in southern Kakadu National Park, the prevention of mining at Guratba by the then Bob Hawke-led Commonwealth Government, and

4 For details of the structure of the Northern Land Council, the most relevant land council in relation to this chapter, see their website: www.nlc.org.au/about-us/our-structure/our-people.

5 See the Aboriginal Areas Protection Authority website: www.aapant.org.au/about-us/history. 
the uncertainty following the High Court recognition of native title in the Mabo case. The Coronation Hill decision was formed around a range of processes undertaken via the NT Sacred Sites Act, the ALRA, the Commonwealth Aboriginal and Torres Strait Islander Heritage Protection Act 1984 and a Resource Assessment Commission inquiry. ${ }^{6}$ The High Court Mabo case saw the broadening of the recognition of pre-existing forms of Indigenous land ownership under the ALRA to a national level, transforming Australian property law and creating a new set of rights for those Indigenous peoples able to demonstrate a continuity of their society with that of their forebears at the time of European arrival. For governments and the mining industry it imposed new requirements, enshrined in the Commonwealth Native Title Act 1993, to negotiate with and compensate Indigenous peoples recognised as holding or potentially holding native title rights over land sought for development (O'Faircheallaigh 2016).

Soon after the Coronation Hill decision, the Keating-led Commonwealth Government, also wary of a post-Mabo negative investment environment, fast-tracked the Mount Isa Mines proposal to commence the McArthur River Mine development. So, by 1993, unique enabling Northern Territory legislation ${ }^{7}$ had been passed to validate the McArthur River mineral leases, and the Native Title Act had been amended to ensure the validity of the McArthur River mineral leases and to apply a non-extinguishment principle and future right to compensation (Young 2009: 8). In this manner, the state-enabled McArthur River Mine commenced operations in 1995 .

As early as 1976 the Gurdanji, Yanyuwa, Mara and Garrwa peoples had sought support from the Aboriginal Land Fund Commission to acquire the McArthur River pastoral lease on their behalf. ${ }^{8}$ Instead, and despite protests by the Department of Aboriginal Affairs in Canberra, the Foreign Investment Review Board approved the sale of McArthur River to Mount Isa Mines in 1977 (Avery and McLaughlin 1977: 3). Avery and McLaughlin wrote:

\footnotetext{
6 See discussion in Lewis and Scambary (2016: 232).

7 McArthur River Project Agreement Ratification Amendment Act 1993 (NT).

8 The Aboriginal Land Fund was established in 1974 by the Whitlam Commonwealth Government during the development of land rights legislation to assist Aboriginal groups around the nation to purchase alienated or private lands.
} 
The attempted purchase of McArthur Station represented for many Gurdanji the last chance to develop their own community in the area. The Station covers core religious sites owned by a wide range of clans. Ownership of the land presented the real possibility for these people conducting an economic cattle enterprise, coupled with traditional foraging practices. (Avery and McLaughlin 1977: 3)

Given that the pastoral lease contained all of the mineral leases and port facilities required to operate the McArthur River Mine, and that had the pastoral lease passed into Aboriginal ownership an almost definitely successful ALRA land rights claim would have ensued, the 1977 sale to the mine operator can only be seen as a strategic move by the Commonwealth and Territory governments to prevent such a land rights claim over the station.

Instead, and nearly 20 years later, in 1994 the Commonwealth entered into the McArthur River Agreement as a compensation deal with the broader Aboriginal community impacted by the project, which included the purchase of the Bauhinia Downs pastoral lease which adjoins McArthur River station some $35 \mathrm{~km}$ east of the mine. This purchase allowed for a subsequent land rights claim to be run over that station, benefiting certain Gurdanji families associated with the McArthur River mineral lease areas, but not all of those whose traditional estates were associated with the Yulanji dreaming tracks along the McArthur River itself and at the mine site well to the east of Bauhinia Downs.

Former senior Commonwealth public servant Brian Stacey notes:

My impression, as a public servant in ATSIC [Aboriginal and Torres Strait Islander Commission] at the time, involved in the administration of the Land Rights Act, was that Aboriginal people were bullied into the McArthur River Mine. I also thought it was a grave injustice to the Aboriginal people of the Gulf who were denied the Right to Negotiate under the Native Title Act 1993. (Stacey 2018: 13-14)

With no land claim, there was no requirement for the company to establish a legal agreement with the traditional owners, and the representative organisation, the Northern Land Council (NLC), was hamstrung in its ability to negotiate with the mining company. In this sense the Commonwealth and Territory governments colluded to create a vacuum from which they absented themselves, leaving the mining company free to 
operate and determine its own community engagement processes with no accountability to any agreement provisions or statutory processes afforded under land rights or native title laws. The traditional owners were left as impoverished bystanders effectively exposed to the whims of the company (Stacey 2018: 14).

The company took this opportunity to strategically apply their substantial resources to control and divide the community, isolating individual senior traditional owners, manipulating local Aboriginal organisations and undermining opposition to the mine. As noted by Kerins:

Reports from the 1990s, when the mine was first being developed, tell how MRM [McArthur River Mine] employees actively worked to separate Aboriginal people from their representative organisations and to create mistrust between them. (Kerins 2017: 12)

\section{Mine Expansions}

In 2002 mine expansion plans for the McArthur River Mine were announced that included a massive open-cut pit on the river-bed of the McArthur River, which would require a $5.5 \mathrm{~km}$ diversion of the river and a bund wall or levee some $100 \mathrm{~m}$ thick and $60 \mathrm{~m}$ high to block the river's wet season flows (Young 2009: 9). These controversial plans soon gave rise to a new political turn. In 2003 global mining giant Glencore purchased the McArthur River Mine and a six-year highly politicised environmental assessment and approvals war raged in the courts, once again pitting the Northern Territory and Commonwealth governments against local Aboriginal people and their cultural, social and environmental concerns represented by the NLC, as well as considerable environmental opposition from environmental groups and broader society. In reaction to various legal defeats over the approvals process the Northern Territory once again enacted remarkable legislation in 2007 to validate the approvals processthe McArthur River Project Amendment (Ratification of Mining Authorities) Act 2007 (NT). When the Federal Court declared the Commonwealth Minister's approvals invalid, the Minister simply reissued his approval in a valid manner, allowing the open-cut development to proceed in February 2009. ${ }^{9}$

9 For a more thorough summary see Young (2009: 9-15). 
Mirroring the 1970s and 1990s, no agreements were in place and Aboriginal rights to and interests in their lands were again ignored, thwarted and overridden by a state that was negatively present in relation to Aboriginal people but very much positively present and active on behalf of the miners (see also Holcombe, Chapter 7, this volume). In 2013 the Northern Territory Government approved the Phase 3 expansion at the McArthur River Mine which allowed for expanded production, enlargement of the open cut and an increase in the size of the tailings storage facility and the footprint and height of the northern overburden emplacement facility (the 'waste rock dump') (Young 2015). Later that year, the waste rock dump began to combust and plumes of sulphur dioxide smoke poured off the mine site for over a year, drawing increased public attention to the project and concern about downstream contamination of the McArthur River itself (Bardon 2016). Glencore's assessment of their waste rock material had proven to be wrong, forcing them into a new environmental assessment process which continues at the time of writing.

In August 2018 the Northern Territory Environment Protection Authority ${ }^{10}$ approved the expansion, purportedly favouring ongoing mining over the risk that the company would abandon the project. The mine still requires authorisation from the Territory and Commonwealth governments, including from the Aboriginal Areas Protection Authority, ${ }^{11}$ which will need to seek Aboriginal site custodians' views regarding the proposed raising of the height of the waste rock dump from $80 \mathrm{~m}$ to $140 \mathrm{~m}$ to match the height of the nearby hill which is a barramundi dreaming sacred site called Damangani (Bardon 2018).

\section{Broken Promises}

I first engaged with the traditional owners of the McArthur River Mine when working as an anthropologist for both the NLC in the mid-2000s, and then in more recent years with the Aboriginal Areas Protection Authority. This latter work involved conducting sacred site clearances in response to applications for Authority Certificates from Glencore, which were precursors to the approvals process for the most current mine

10 The NT independent statutory authority established by and to administer the Northern Territory Environment Protection Authority Act 2012.

11 The NT independent statutory authority established by and to administer the Northern Territory Aboriginal Sacred Sites Act 1989. 
expansion proposals (as described above). Based on this work, which involved various mine site visits, aerial and ground-based sacred site surveys and work on surrounding matters, I came to know the key traditional Aboriginal owners and site custodians for the mine and its surrounds and gained insight into company practices and their community relations.

During this time a senior man, Mr Coolibah, was active as a senior Gurdanji nimirringi (or 'owner') for the Mambaliya Wurrini estate on the McArthur River at the mine site. A regular informant for my work, he held strong knowledge of his estate and worked closely with a cohort of other nimirringi and junggayi ('managers') for his own as well as neighbouring estates and others with traditional connections to the mine area. ${ }^{12} \mathrm{He}$ had emerged as a senior figure as the 2000s progressed and with the passing of his predecessors and senior Aboriginal figures of the region such as Harry Lansen and Bruce Joy. Throughout my work with him, Coolibah was a quiet but firm man seeking to improve his and his family's lot while clearly being caught between the manipulations and promises made by the McArthur River Mine 'company men' and his broader cultural obligations to sacred sites, country and his fellow 'countrymen'. Trapped by the historic chicanery of the state and the company, Coolibah and the rest of the Gurdanji have been marginalised in relation to the mine while other Northern Territory Aboriginal groups with mining projects on their lands have been able to negotiate benefits under the ALRA. The Gurdanji have experienced this powerlessness in the face of incomprehensible expansions to the mine, destruction of their lands, disturbance and contamination of their waters, and constant threats to their sacred sites.

In 2016 Coolibah was diagnosed with terminal cancer and after treatment in Royal Darwin Hospital he returned home and died in February 2017 surrounded by family. During my many field trips, numerous phone conversations and other engagements with him he regularly spoke at length about the mine and its impacts on him, his people and his society.

12 Aboriginal society in the Gulf region (and many surrounding regions) recognises complementary affiliation to land which involves the transmission of rights in country along lineages of patrilineal descendants, who are considered to be 'owners' of an estate of land and its sites and dreamings. Complementary rights are transmitted via matrilineal connections to the same estate with matrifiliates considered to be 'managers' or 'police', whose role it is to ensure that the owners are caring for their country, sites and ceremonies appropriately. In the Gulf region the respective label for 'owner' is nimirringi and for 'manager' is junggayi. Also see further discussion in the chapter. 
The following is a selection of Coolibah's reflections which I collected across my various times with him which I have paraphrased:

They gave me my block, dongas, motor car, bus, money, tank and fencing-that made me a little bit happy. But we didn't understand - we knew about the old mine, but didn't know it [the open cut and diversion] was going to be such a big mess.

$\mathrm{Me}$, Bruce and Ronnie tried to stop it [the mine expansion] with a lot of other people. Didn't know it was going really open like that, change that river-you can't do that! We could see they gone in like a mob of worms under the ground, like a mob of termites or pigs digging everywhere [on seeing the underground operation being opened up].

They ask me I must've been stupid - me and the others. Old Harry was right he tried to block it. We tried to push them to get royalty. They bin breaking my promise man Bruce.

Mining company want to keep going higher for that dump. We said you asking too much-you need to give us good deal not rough deal. No higher than the barramundi they promised. Now they still asking. Everything changed and biggest mess since company came. Feel no good, sick, I can't stand it.

Broken promises make me angry. That dreaming tree if that goes they gotta get something back.

Muminini they already broke him with the bucket. Yakuwala they already broke that one. ${ }^{13}$ Any more damage they gotta get a good deal. I'm sad, sick and worried. Gotta go this mine.

That open cut-you have to blame me for that-I was stupid. My junggayi both said yes. I had to follow that line. Our way I have to follow them—old days you get belted if you ignore them.

That river diversion the snake line been damaged. That bund wall the Garbula tree gonna get poisoned. Downstream-fish, watercan't eat fish anymore we frightened.

That open cut—my head wasn't working that day. I had no power.

13 During earlier mine works a bulldozer ('the bucket') cut into Muminini, a sacred hill near the mine, and rocks were disturbed at Yakuwala another sacred site located close to current mine infrastructure. 
Coolibah's Aboriginal English was good, but the difficulty of communicating the impacts of damage and loss in a brief set of statements is immense (a common challenge with other sacred site matters I have worked on). Not only are these intangible personal and spiritual matters, but they occur within a cultural framework and normative system that never considered industrial-scale damage to land or sites (see Lewis and Scambary 2016: 244-5). In order to explore what Coolibah was seeking to communicate in these paraphrased statements, they need context, expansion and some interpretation.

In the late 2000s the mining company gifted Coolibah a small block of land on McArthur River station near Garanbarini conservation reserve north of the mine. The company also provided some transportable buildings to establish a small outstation. My earliest interactions with Coolibah in the early 2000s were often about his frustrations with this promised outstation. His comments above indicate that he considered this outstation to be personal compensation for the initial 'old' mining operations and the 1994 Commonwealth compensation deal which gave Bauhinia Downs to other Gurdanji people, principally Harry Lansen's family. As Coolibah's traditional Wurrini estate does not extend westwards to Bauhinia Downs, he and his immediate family did not directly benefit from the return of Bauhinia Downs. In this sense Coolibah is saying that his outstation and the few ex-mine buildings that he received from the mine were part of what he had always expected and demanded from the miners (and by implication the state) as compensation from much earlier events in the mid-1990s.

Coolibah's words also express his and other traditional owners' lack of any comprehension of, let alone any free prior or informed consent for, the expansion of the McArthur River Mine to an open-cut project. He laments not following Harry Lansen's resolute opposition to the mine expansion, realising that he and others got caught out trying to get a royalty deal from the company. He notes the shock of the transformation of the landscape with the open cut and the river diversion and he notes that the company 'broke' his junggayi Bruce Joy, his now deceased 'promise man'. This was Coolibah's way of saying that it was Bruce who gave in to company pressure and said yes to the expansion work and that he himself had to follow his junggayi. Precisely what Coolibah meant by 'broke' remains conjectural: it could mean that the company broke Bruce's resolve, contributed to his death or both. 
The nimirringi-junggayi relationship remains prominent in Gulf Aboriginal society. ${ }^{14}$ Enshrined in ceremonial practices and in the codification of relationships to land this relationship extends into mundane life where the nimirringi will seek the approval of his or her junggayi for many decisions even in relation to apparently daily or trivial matters. It is always critical for the nimirringi to include their junggayi in land business, sacred site or cultural matters; failure to do so will usually result in acrimony and fines. In the context of McArthur River Mine approvals, Coolibah was implying a degree of self-redemption in that he was seeking to spread his own culpability for his decisions amongst his contemporaries.

Coolibah spoke of impacts of the latest expansion proposals on the Damangani sacred site, which is the hill associated with a barramundi dreaming immediately north of and downstream from the open cut. The waste rock dump is the subject of ongoing approvals processes with Glencore, who are seeking to increase the height of the current waste rock dump design. This was the subject of much earlier Aboriginal Areas Protection Authority Certificates where the original waste rock dump design was limited in height to $80 \mathrm{~m}$ in order to allay the concerns of Aboriginal custodians about perceived impacts on the integrity of the nearby Damangani sacred site. Attempts to dishonour this deal are read by Coolibah and others as a broken promise by the company.

The Garbula tree is another sacred site located within $50 \mathrm{~m}$ of the base of the open cut bund wall on the southern side of the McArthur River Mine pit. I visited this site on a few occasions with Coolibah and others and the decontextualisation of this and other sites from their natural state (and their proximity to the mine developments) have been a long-standing source of concern. ${ }^{15}$ This tree and others upstream, along with nearby permanent waterholes on the McArthur River, are manifestations of two Yulanji rainbow serpent dreamings which converge at this point of the river. These and other sacred places associated with Gurdanji ceremony and ritual are encompassed within the mineral leases controlled by the mine, which has effectively restricted access to them by Gurdanji and other

\footnotetext{
14 See Footnote 12 for more detail.

15 See Bainton et al. (2012) for a comparable example of a decontextualised (or re-contextualised) sacred geography at the Lihir gold mine in Papua New Guinea.
} 
Aboriginal people for a generation. ${ }^{16}$ In my experience of site clearance work which required access to these sites with custodians, the irony is not lost on these custodians that the only time they can readily achieve access to these sites is when the company requires a site clearance for its own needs. Coolibah's words 'Broken promises make me angry' barely capture the frustration, anger and sense of loss and despair that was palpable during such visits. The threats posed to sacred sites by the evolving works at the McArthur River Mine echo previous experiences where other sacred sites, such as Muminini and Yakuwala, were damaged by earlier mining activity in the 1970-80s. Coolibah was expressing concern about any more damage to sites and what this meant to his personal health-he was 'sad sick and worried' by such threats. By 'a good deal' he is alluding to potential compensation for mining and site damage, which I read as an attempted warning and reassertion of his traditional authority as well as his need to be seen by others, especially his junggayi, to be exercising his traditional responsibilities by punishing transgressors. When Coolibah stated 'That open cut - you have to blame me for that-I was stupid', he was particularly tearful and it was the first time that I had heard him admit any fault or blame. While, as noted earlier, he qualified this confession at least in part by blaming Bruce Joy as his junggayi, it was clearly a powerful and painful realisation.

The diversion of the river has been regarded by many site custodians as damaging the dreaming track followed by the two Yulanji or rainbow serpent dreamings, one from the north and the other (Coolibah's) from the south which converge at the mine site. Coolibah notes the fears held by himself and his broader Aboriginal community about downstream contamination and impacts on their use of traditional resources.

The key theme which emerged consistently in my engagements with Coolibah, represented in the statements presented above, was the trope of the 'broken promise man' which I understood from him to be a multivalent figure that changes in identity as well as temporally to encompass a range of figures both real and conceptual who embody and enact moral uncertainty. The broken promise man is the mining company men who worked on Coolibah over many years manipulating and incentivising his tacit support when needed by making new promises, while delaying

16 Section 47 of the Northern Territory Aboriginal Sacred Sites Act 1989 preserves the right of Aboriginal custodians to access sacred sites located on private land. This right has been heavily mediated at the McArthur River Mine as an active mine site with occupational health and safety risks. 
on older promises for his outstation. The same mining company men damaged sacred sites at Muminini and Yakuwala in the past, and now threaten to destroy the Garbula tree and undo earlier promises (and agreements) made about limiting the height of the waste rock dump in relation to the barramundi dreaming at Damangani. The state (in the collective sense of both the Commonwealth and Northern Territory) is also the broken promise man who disempowered Coolibah and his fellow traditional owners by thwarting their land rights and native title claims, denying them the right to a full prior and informed consent process and therefore any negotiating power in relation to the McArthur River Mine. ${ }^{17}$ Coolibah's junggayi Bruce Joy was also the broken promise man, in that according to Coolibah, he succumbed to the pressure and inducements made by the mining company and by approving the mine expansion, he forced Coolibah as his nimirringi to follow him. Finally and tragically, the broken promise man emerges as Coolibah himself, who through tears of regret faced his failures, realised that he too had been manipulated by the mining company, marginalised by the state, and ultimately had broken his own promise- his duty to care for his traditional lands and ancestral sites.

Coolibah's broken promise man ultimately embodies his personal powerlessness, and that of his regional Aboriginal community, in the face of a long history of events unfolding around him associated with the mine. The state's elusive role in facilitating the development meant that the face of Coolibah's protagonists were never fixed and were forever moving like dancers around him, underscoring the moral and institutional uncertainty of this figure. Throughout the years I knew him and despite his best efforts, he never managed to engage with the state as the power behind the mine, because unlike the company men, the state actors were never present or accessible to him (see also Skrzypek, Chapter 2, this volume). The power of the state, embodied and exercised in the activities of the company, have produced what Fredericksen and Himley (2019: 58-9) call extractive subjects, in the form of Coolibah and his countrymen, who are simultaneously shaped by the exercise of power relationships at this extractive frontier and integrated into regional, national and global extractive economies.

17 I think that while Coolibah probably understood that these layers of government were geographically and politically distinct holding different powers, like many Aboriginal people of his era and older, he did not differentiate between the two. Both were seen as 'Government mob', a unified form of externalised non-Indigenous power. 
I was unable to attend Coolibah's funeral in Borroloola but a colleague recalled the event to me as one dominated by high-visibility work shirts, corporate logos and a funeral procession led by a Glencore-marked trayback utility carrying Coolibah's coffin. The eulogy was read by the company man most associated with Coolibah, the Health, Safety and Environment Manager, who recalled his friendship and noted with apparent pride that Coolibah had given him an Aboriginal name. Upon hearing this I recalled Coolibah telling me during a site survey a few years earlier that he had given this man a name which was intentionally unflattering and reflective of his role in a litany of broken promises made by the company. So it was with deep irony that this company man, one of Coolibah's broken promise men, eulogised his 'friend'. In death Coolibah was fully appropriated by the company, at least symbolically via the funeral, transforming him from an excluded, vociferous and politically volatile character, into a remembered, revered and now silent unproblematic stakeholder. Glencore had, to use Fredericksen and Himley's terms (2019: 59), transformed Coolibah from an extractive subject into the perfect extractive citizen.

\section{Open Cut I Cut Open}

A few months after Coolibah's death, an exhibition of artwork and photographs protesting the McArthur River Mine was launched in Darwin's trendy market and gallery precinct of Parap. The modest exhibition of seven paintings by Jacky GreenWarngkurli, accompanied by a series of black and white portrait photographs of Gulf Aboriginal people by Therese Ritchie, was orchestrated by Sean Kerins, a research fellow at the Centre for Aboriginal Economic Policy Research at The Australian National University (Figure 8.2). Jacky is a Garrwa Mambaliya man who I have worked with alongside other Gurdanji custodians, including Coolibah, on sacred site clearances at the McArthur River Mine. His long-standing public opposition to the project has meant that he is not popular with Glencore, who have resisted his access to the mine site and questioned his traditional connections to the area. In my experience Jacky's ceremonial connections to sites at the mine and his broader knowledge of regional matters has meant that he has been considered by all senior Gurdanji to be an essential part of the sacred sites work that I undertook. 
The 2017 exhibition was entitled 'Open Cut'. One wall was occupied by a selection of Jacky's uncompromising paintings depicting the mine and environmental and cultural damage it has reaped upon the lands and people of the Gulf. Each painting was accompanied by a text from Jacky providing his insight into the mine and its irreconcilable conflict with his cultural values and those of his community. One example is the painting entitled Red Country (see Figure 8.3).

The exhibition catalogue for this piece reads:

\section{Red Country}

Right across the McArthur River region are The Dreaming tracks of the ancestral beings. The barramundi, the two snakes who travelled together and the one that come up from the south. The Rainbow Snake and the Stinking Turtle. They all there. So too are the places where they coiled or rested, or went down under the earth like at the place I have marked in the river. Big name places, important and sacred places, they are right across the region and they tie people to places and people together.

Right in the middle of this sacred country is a torn-up place, right where the Sacred Tree is that forms part of the Rainbow Snake story. It's a big name place, right where the massive open cut pit now is. The black represents the hole that keeps getting bigger and bigger and the brown represents how the mining company is now talking about stuffing all the toxic waste rock back in the hole before they take-off with their money and leave us and generations to come with their toxic mess. (Green et al. 2017)

Such irreconcilable contestation over resource extraction in the Northern Territory has been a theme that I have noted elsewhere with Benedict Scambary:

This pattern of conflicting interests demonstrates how such contests have commonly focussed on and been articulated around matters of Aboriginal sacred sites. They have involved the collision of interests where areas of geological and mineralogical significance in the form of mineral deposits and ore bodies coincide with places of cultural significance to Aboriginal people in the form of sacred sites. (Lewis and Scambary 2016: 222) 


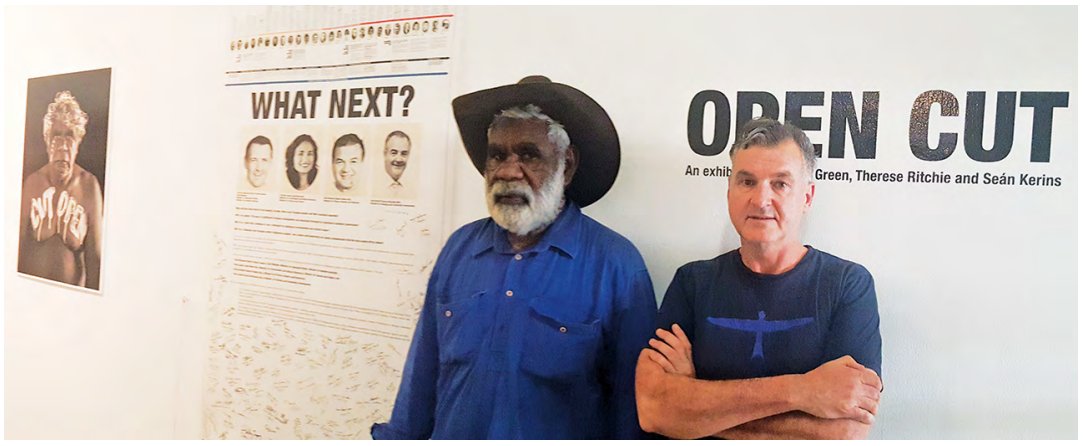

Figure 8.2 Jacky Green and Sean Kerins at Open Cut, Darwin, 2017 Source: Photograph by author

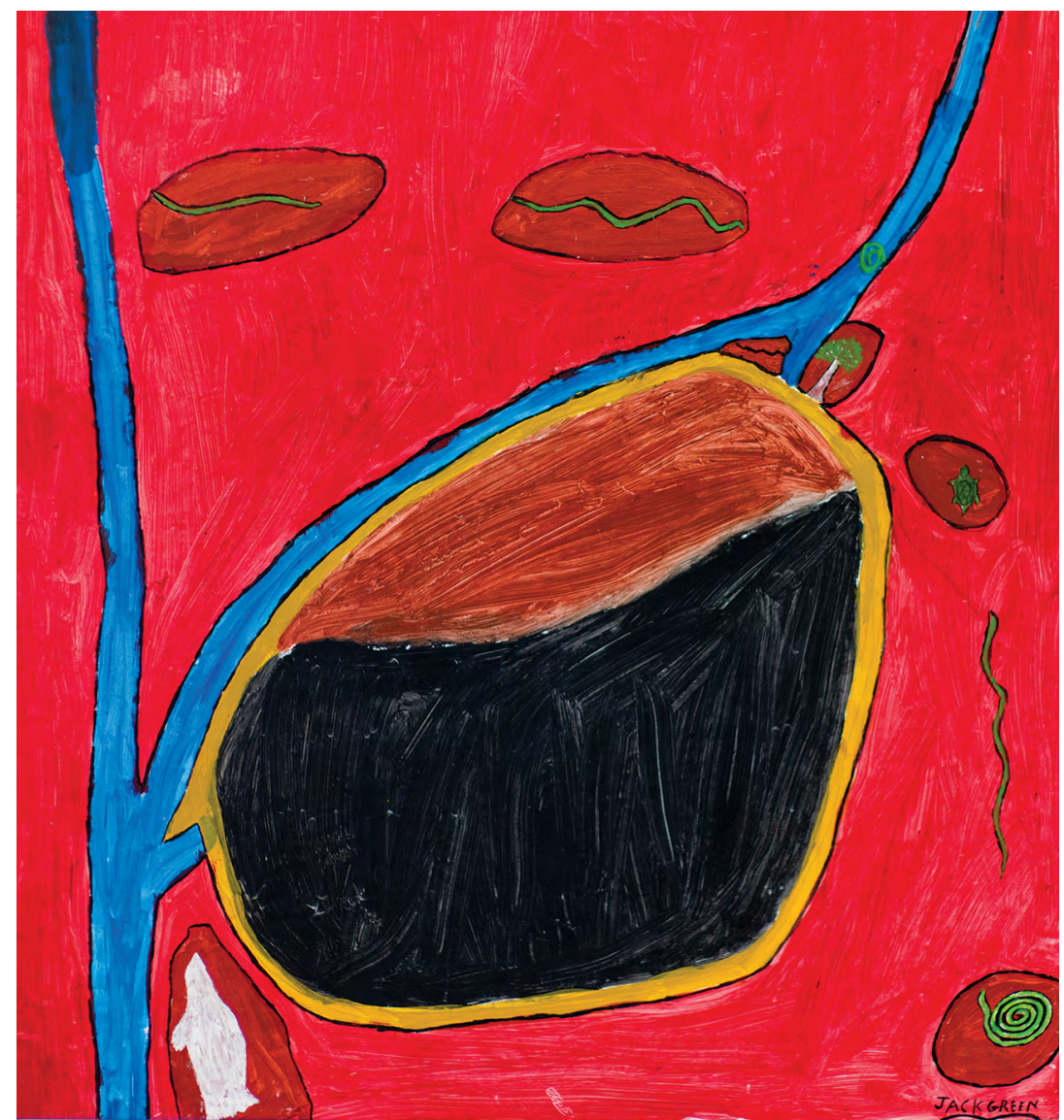

Figure 8.3 Jacky Green, Red Country, 2017, 96 x 88 cm, acrylic on canvas

Source: () Jacky Green 
On the wall opposite Jacky's paintings were a set of black and white photographic portraits taken by Therese Ritchie of Gulf Aboriginal people with words and statements painted across their bodies in English and Garrwa. Jacky's portrait has 'Cut Open' across his chest, others include 'Intergenerational Despair', 'Hope', 'Lead', 'Sovereignty' and more. Kerins notes:

Just as previous generations of Aboriginal people from the Gulf country have used artistic expression to make their voices heard and their feelings known, Aboriginal people in the Open Cut exhibition continue to do so, scarifying their bodies to speak to power. (Kerins 2017: 13)

Such use of the body to communicate with the broader community reflects the heart of this contest over resources. As Scambary and I previously wrote, and extending from the above quote:

The phrase sacred bodies is used here with the intent of drawing focus onto the physical, and very much bodily, relationships which exist between place and people in Aboriginal Australia, as well the cultural, emotive and religious systems and traditions which underpin these relationships. We consider that such an emphasis is reflective of Aboriginal discourses about the impacts of damage to sacred sites ... how the literal undermining of Aboriginal sites damages individuals, tears at the fabric of their societies and undermines the very ability of already vulnerable cultural groups to reproduce their traditions and thereby themselves. (Lewis and Scambary 2016: 222)

Prior to the 2017 exhibition, I was undertaking non-McArthur River Mine related fieldwork in Borroloola, Jacky took me aside and proudly showed me his 'little song' he had written about Ngabaya 'the devil'. The key lyric components as explained by Jacky were: Ngabaya [devil] ngyirridji [fiddles] gunindjba [digging] ('the devil that fiddles and digs in our country').

The Ngabaya is a generic dreaming figure prominent at sacred sites and dreaming tracks which cross the region. Ngabaya, often called 'devil', is more accurately an anthropomorphic spirit figure of ambivalent nature rather than embodying any evil in the Christian tradition. ${ }^{18}$ I mistakenly

18 As John Bradley and Yanyuwa families note (2010: 195): 'The generic term ngabaya refers to any human-like spirit being, often translated as "ghost", "spirit" or sometimes by the Kriol term debildebil ("devil", which although probably originating in Christian teaching, was not generally thought of as a spirit of greater evil than other spirits)'. 
interpreted Jacky's song to be demonising the mining company, but Jacky corrected me and described his more nuanced use of this character as referring to:
anyone who messes about with country and damages things- it can be a mine operator, an Aboriginal person on a grader or a government bloke ... anybody, they are dangerous because they don't understand, they interfere and cause trouble ... (Jacky Green, personal communication, January 2017, Borroloola)

With a multivalence similar to Coolibah's 'broken promise man', this song about the Ngabaya was performed by Jacky along with other songs at the opening of the Open Cut exhibition in Darwin. On the end wall of the Open Cut exhibition was an annotated graphic timeline connecting the contact history of the colonial frontier 'wild times' with the policy environment of the present-which might be interpreted as a way of using memory to cope with uncertainty. Illustrated with photos and 'credits' for the notable actors in the history of the Gulf generally and the McArthur River Mine development in particular, this timeline presents like a wall of shame graphically demonstrating the connections between past and present for Aboriginal people of the Gulf region. Reflecting on the images displayed on the wall including their own photographic portraits, Gulf artists Stewart Hoosen ${ }^{19}$ and Nancy McDinny ${ }^{20}$ were quick to draw parallels between the violence of murderous frontier times to current experiences of marginalisation alongside the cultural and environmental damage inflicted by the McArthur River Mine. There is a consistency in this experience underpinned by the malevolent role of the state both past and present.

\section{The Malevolent Absence of the Neoliberal State}

For the Gurdanji, Yanyuwa and Garrwa in the Gulf, as for many Aboriginal people affected by other resource extraction projects across the Northern Territory, the state is often perceived as an absent actor. Engagement between miners and Aboriginal people has either been direct or preferably mediated by effective Indigenous representative organisations such as land

19 See Cross Art Projects (2017a).

20 See Cross Art Projects (2017b). 
councils using legislative frameworks such as the ALRA or the Native Title Act. The Northern Territory experience of visiting politicians courting favour with and seeking project approvals from Aboriginal leaders during the early land rights era of the late 1970s and 1980s has faded. Safari suits have given way to high-vis shirts and hard hats as the neoliberal state has increasingly withdrawn from its remote servicing interests and responsibilities in favour of, and deference to, corporate community benefits packaged up as a social licence to mine, in what can be seen as an outsourcing of state responsibilities (see Scambary 2013: 9-10; see also Everingham et al., Chapter 9, this volume).

As noted earlier Australian Indigenous affairs has been the subject of major policy shifts over the last 40 years. The most recent of these shifts has been generated around the application of neoliberalism, which has witnessed the extension of market mechanisms into areas of the community previously organised and governed in other ways, especially in Indigenous communities, allowing for a broad reduction in the ambit and role of the state (Howlett et al. 2011: 312). ${ }^{21}$

From the self-determination era which ushered in land rights, Indigenousspecific policy making and a decolonising approach in the late 1970s, to the revival of assimilationism and mainstreaming policies of the Howard Government in the 2000s, current approaches to universalise, 'westernise' and 'incorporate' remote Aboriginal populations have, according to Jon Altman:

been a mix of politics, ideology and cultural critique that has driven the current policy project to neoliberalise geographically remote Aboriginal people so as to free them from a relational ontology that emphasises commitment to family and kin, ties to place, and obligations in ceremony. (Altman 2014: 124)

For the mining industry operating across the physical and policy space of Indigenous Australia, the balance between unimpeded development, statutory requirements and social legitimacy or licence has both followed and influenced these spaces. From the dire warnings of industrial collapse in the face of land rights as companies were dragged into agreement-making processes with the Northern Territory land councils, to the seemingly enlightened community engagement approaches from the mid-1990s,

21 For thorough summaries of the Australian context see Altman (2014) and Howlett et al. (2011). 
there have been many shifts in these balances. ${ }^{22}$ Bound up in fluctuating terms such as 'community engagement', 'social licence', 'social licence to operate', 'social sustainability' or 'corporate social responsibility', the role and responsibility of mining companies in local as well as broader community affairs has become increasingly scrutinised in recent decades. Whether driven by demands from activists, civil critique, community pressure or by shareholder demand, the need to at least claim to be creating 'social value' or 'delivering benefits' has been driven more from within the industry rather than through any particular state intervention.

In my experience with the McArthur River Mine and elsewhere, social value via community engagement is a function often lumped in with the duties of other operational disciplines such as human resources, public relations, environment, or occupational health and safety. It was the Health, Safety and Environment Manager who played the key role in engaging with Aboriginal traditional owners such as Coolibah (including eulogising at his funeral, as noted earlier), and facilitating site visits at the McArthur River Mine. At the OM Manganese mine at Bootu Creek near Tennant Creek it was a staff member in a similarly titled role that organised liaison committee meetings, mine site visits, and fencing around an identified but ultimately ill-fated and desecrated sacred site (Lewis and Scambary 2016: 235-9).

The commentary I have received from the communities subjected to these engagement roles suggests an unsophisticated yet highly selective approach of capturing senior traditional owners. This commonly occurs via rudimentary support in the form of directing jobs to immediate family members, and/or providing valued resources such as spare parts or tyres for vehicles. Such forms of 'social value' or 'community benefit' appear to be driven purely by corporate self-interest seeking to appease and manipulate potentially problematic individuals_creating extractive subjectsrather than by any underlying ethic or desire to meaningfully support communities impacted by their operations or to mitigate these impacts.

John Owen and Deanna Kemp (2017: 33) identify the vagaries of terminology as one part of the problem. Being a poorly defined, metaphorical and intangible concept, social licence (or social licence to operate) in mining has been interpreted and applied inconsistently

22 For an excellent summary of these shifts in relationships between the mining industry and Indigenous peoples in Australia see Altman (2009: 2-27). 
by industry, regulators, commentators and impacted communities. In their analysis of the global mining industry this manifests as a counterproductive clash between an industrial ethic (where companies are exclusively focused on profit) and countervailing powers which seek to resist corporate control, influence and impact. Building on Galbraith's modelling of such countervailing powers, they argue that an effective and mature 'social function' within mining companies is required to moderate their own self-interest (Kemp and Owen 2018: 492) and help to minimise some of the most perverse impacts upon local communities. The absence of this social function perpetuates self-interest and unleashes a range of consequences.

As detailed earlier, within this industrial and state policy framework, the McArthur River Mine has been allowed to occupy a unique space created by the state to ensure that the development of the project was unimpeded by Aboriginal land claims or native title claims. The state both actively removed what could have been a legitimate external countervailing power to the project, and allowed and legitimised the absence of any effective social function (or internal countervailing power) within the project. Kemp and Owen have observed a global decline in corporate commitment to the development of the social function and the capability to manage the social aspects and impacts of mining. They argue that 'the demise of the social function will only be reversed, or rebuilt, if and when the industry is subjected to ... conflicts and scandals that cannot be concealed by the machinery of public relations' (Kemp and Owen 2018: 498). But in the case of the McArthur river mine, such scandals and conflicts have thus far had little impact upon the company.

In their work on transnational governmentality and resource extraction, Suzana Sawyer and Edmund Gomez state that 'Common wisdom holds that public-private collaborations among governments, IFIs [International Financial Institutions] and multinational corporations (MNCs) will enhance social well-being by eradicating poverty, promoting sustainable forms of economic development, protecting the environment and advancing the rights of indigenous peoples' (Sawyer and Gomez 2008: iii). Contrary to this common wisdom, it is recognised that there are 'monumental' and 'baffling' problems and growing concerns over the adverse impacts of resource extraction projects on Indigenous peoples across many nations. Sawyer and Gomez note that despite many government and corporate attempts to create inclusive consultative institutions aimed at affording Indigenous peoples property, veto 
and other empowering rights over resource extraction projects, the majority of Indigenous peoples find themselves increasingly subjected to discrimination, exploitation, dispossession and racism (2008: 1). The public-private partnerships they have reviewed, including case studies from Australia, demonstrate how a combination of institutional capture, clientelism and political positioning undermines the neutrality of the state and its capacity to protect Indigenous communities. They see this manifest most conspicuously through the funding of political parties by mining corporations and key appointments made to the boards of directors of international financial institutions. Mining companies have then used such donations and appointments to influence state policies and laws to serve their interests.

For the McArthur River Mine such capture is evident in the earliest stages of the project via the legislative support and approvals processes described earlier. In September 2017, Rod Campbell of the Australia Institute reviewed the economic modelling for the Phase 3 expansion of the McArthur River Mine which Glencore claimed will generate tax and royalty payments of over AUD1.5 billion. His findings deplore these claims as based on assumptions which he found to be 'almost comical'. $\mathrm{He}$ summarises that their modelling included payroll tax payments over a thousand years to the year 3017, estimates of AUD435 million in royalty payments - which are not actually paid at all in most yearsand estimates of AUD1,035 million in company taxes when Glencore regularly pays no company tax at all in Australia.

Adding to this picture, the September 2017 disclosure that the size of Glencore's environmental bond for the McArthur River Mine, at AUD476 million, is estimated to only cover 25 years of mine life and rehabilitation when the actual costs are likely to extend for hundreds of years (Vanovac and Breen 2017). ${ }^{23}$ Campbell concludes his analysis by pointing out that:

The NT government estimates their cost of cleaning up abandoned mines in the NT would be over $\$ 1$ billion. Given this history and the present reality of the McArthur River Mine's impacts on the environment and local community, it is likely that the environmental costs imposed by the mine will be far greater than the uncertain revenues that could be generated. From an

23 This disclosure was only possible after legal action taken by Jacky Green, represented by the Environment Defenders Office of the NT. 
economic perspective, it is likely that the best approach would be to close the mine and rehabilitate the site, and to ensure this is paid for by Glencore. (Campbell 2017: 17)

Barrister Anthony Young has also reflected on the long record of failings of the environmental assessment process at the McArthur River Mine by successive Northern Territory and Commonwealth governments. He cites deliberate and reckless political choices and the ignoring of scientific and expert advice, which amplify the potential for the mine to cause catastrophic environmental damage:

The history of the McArthur River mine shows that governments are willing to sacrifice the health of the environment and of those directly reliant on it, such as the Aboriginal people of the region, to the mining industry and economic interest. (Young 2015)

The Phase 3 process appears to follow this trend with Glencore forced into a new approvals process after its failings in its assessment of the composition of waste material being placed on the NOEF materials [the northern overburden emplacement facility, or waste dump]. (Bardon 2016)

This mirrors the international findings of Sawyer and Gomez (2008: 28) who note the failings of self-regulated corporate social responsibility where the state is too easily compromised by the overwhelming influence of transnational capital (see also Bainton and Macintyre, Chapter 4, this volume). The state cannot effectively regulate or monitor what it is authorising in the name of investment or development. Sawyer and Gomez identify transnational solutions:

What is required is not public-private compacts but an effective arms-length and accountable relationship between governments and MNCs [multinational corporations] to deal with corruption, environmental degradation and violence. A viable institutional framework is thus required to honourably compensate local populations, including indigenous peoples, for the disruptive effects of resource extraction, not involving the state, given that it lacks neutrality, but an independent monitoring body, such as the UN (and possibly NGOs). (Sawyer and Gomez 2008: 28)

I have argued above that this accountability and a compensatory approach to the McArthur River Mine was available but avoided by the state from the start. Had a land purchase over McArthur River Station been allowed in the mid-1970s and had the ALRA been allowed to run its course, an 
agreement would have ensued between the traditional Aboriginal owners and the company mediated by the NLC, an independent Commonwealth statutory body. Such an agreement, while not necessarily addressing all environmental matters at the mine, nor addressing all matters for all local Indigenous peoples, would have still been an empowering move, the benefits of which are now impossible to quantify. Instead what emerged in relation to the McArthur River Mine is that the state, in the form of both the Territory and Commonwealth governments, has been captured by extractive capital interests and actively undermined readily available solutions of the very sort identified by Sawyer and Gomez. In removing itself as much as possible in order to acquiesce to extractive interests, the malevolence of the state is thoroughly discernible.

Adding to the analytical commentary above, the McArthur River Mine has also attracted regular negative media coverage and reporting on aspects of Aboriginal opposition, environmental failures and regulatory concerns. In the face of such criticism and concern, the state approvals for the project have flowed. It seems that despite such coverage, controversy and opposition, there has been little cause for alarm at Glencore headquarters and at the mine site: no discernible social function exists while their promining commercials roll out regularly on Darwin television, which might be interpreted as a stronger corporate commitment to public relations than to actual local community relations.

The impoverished countervailing power of Indigenous interests expressed in the words of Coolibah and the protest art and imagery of people such as Jacky Green in Open Cut may have limited direct impact on corporate power, but it can at least draw this power to funerals and public protests, like the Open Cut exhibition. It demonstrates the unease which can be generated by the mobility of extractive subjects as unpredictable and uncontrolled characters. Just as Coolibah was his own broken promise man, Jacky Green in this sense embodies his Ngabaya figure, interfering with and disrupting the corporate power exerted on him and his fellow extractive subjects. Like other forms of Indigenous protest and opposition to mining, the mobilisation of art, words and story in social and other media in Open Cut appears to also be generative of reaffirmations of cultural beliefs and local discourses blending themes of cultural revival and resistance. ${ }^{24}$

24 See discussion in Lewis and Scambary (2016: 246-7). 


\section{Conclusions}

The various operators of the McArthur River Mine have been the beneficiaries of a state that has been positively present for resource developers and negatively present for Aboriginal communities—evidencing a dialectical relationship between the absence and the presence of the state. The mine operators have benefited from Territory and Commonwealth government approvals and manoeuvring to thwart Aboriginal land claims and agreements and from unique legislative measures and amendments to negate all legal challenges to date. This situation also suggests a dialectical relationship between the institutional capture and the political positioning of the state. The captured state, whether located in Canberra or Darwin, has advocated at the highest possible levels for this development while absenting itself from the locale of development and divesting its functions into decentralised and distant forms of regulatory and corporate power.

For the Aboriginal people of the Gulf, the captured neoliberal state has maintained the malevolent absence of the colonial state. Bound up in the same development agenda, with a shift from cattle to base metals, and employing comparable if less violent techniques of divesting power over local affairs into the hands of remote self-interested parties, while absenting itself from the consequences. In the expressed perceptions, transmitted memories and experiences of the Aboriginal people of the Gulf, the state has exercised a malevolent absence across the region for 130 years. Absent decision makers have wielded power from afar directing punitive police raids, arming pastoralists and civilians, and approving mineral leases and mine expansions. The malevolent and selectively absent state looms as the agency behind Jacky Green's Ngabaya devil figure instantiated in art, song and protest, and emerges within Coolibah's dying attributions, confessions and absolutions of the broken promise men-it has subjectified Aboriginal people of the Gulf first as colonial subjects and now as extractive subjects.

Returning to the quote from Jacky Green prefacing this chapter, it was they that cut us open, they that pushed us aside, they who invaded. This collective and multivalent otherness of they - the police, the pastoralists, the miners, the Whites-has been consistently empowered by the state feigning absence yet looming malevolently present. As the authority behind massacres inflicted so recently that the victims include the grandparents of the remaining current senior generations of Gulf Aboriginal people- 
and as the authority preventing current and future generations from protecting their cultural sites and from sharing in the benefits being extracted from their traditional lands - the state has ultimately failed to protect its Aboriginal subjects and citizens of the Gulf, breaking its most fundamental of promises.

\section{References}

Altman, J., 2009. 'Indigenous Communities, Miners and the State in Australia.' In J. Altman and D. Martin (eds), Power, Culture, Economy: Indigenous Australians and Mining. Canberra: ANU E Press (Centre for Aboriginal Economic Policy Research Monograph 30). doi.org/10.22459/caepr30.08.2009.02

, 2014. 'Indigenous Policy: Canberra Consensus on a Neoliberal Project of Improvement.' In C. Miller and L. Orchard (eds), Australian Public Policy: Progressive Ideas in the Neoliberal Ascendancy. Bristol: University of Bristol, Policy Press. doi.org/10.2307/j.cttlggjk39.13

Avery, J. and D. McLaughlin, 1977. 'Submission by the Northern Land Council to Aboriginal Land Commissioner on Behalf of Traditional Aboriginal Owners in the Borroloola Region of the Northern Territory.' Darwin: Northern Land Council.

Bainton, N.A., C. Ballard and K. Gillespie, 2012. 'The End of the Beginning? Mining, Sacred Geographies, Memory and Performance in Lihir.' Australian Journal of Anthropology 23: 22-49. doi.org/10.1111/j.1757-6547.2012. 00169.x

Bardon, J., 2016. 'The Race to Avert Disaster at the NT's McArthur River Mine.' Australian Broadcasting Corporation, 12 February. Viewed 25 September 2020 at: www.abc.net.au/radionational/programs/backgroundbriefing/the-race-toavert-disaster-at-the-nts-mcarthur-river-mine/7159504

, 2018. 'EPA Recommends McArthur River Mine Expansion, Despite History of Environmental Incidents.' Australian Broadcasting Corporation, 11 August. Viewed 25 September 2020 at: www.abc.net.au/news/2018-08-11/ mcarthur-mine-river-expansion-recommend-epa-glencore-environment/10 108052

Bradley, J and Yanyuwa families, 2010. Singing Saltwater Country: Journey to the Songlines of Carpentaria. Sydney: Allen and Unwin.

Campbell, R., 2017. 'Wishful Zinking: Economics of the McArthur River Mine.' Canberra: Australia Institute. 
Cross Arts Projects, 2017a. 'Stewart Hoosan.' Video, 4 December. Viewed 13 October 2020 at: youtu.be/0BRqjOf3oI4

, 2017b. 'Nancy McDinny.' Video, 4 December. Viewed 13 October 2020 at: youtu.be/etu9XJHpo4A

Frederiksen, T. and M. Himley, 2019. 'Tactics of Dispossession: Access, Power, and Subjectivity at the Extractive Frontier.' Transactions of the Institute of British Geographers 45: 50-64. doi.org/10.1111/tran.12329

Green, J., T. Ritchie and S. Kerins, 2017. 'Open Cut: An Exhibition by Jacky Green, Therese Ritchie and Sean Kerins.' Darwin: Northern Centre for Contemporary Art.

Howlett, C., M. Seini, D. McCallum and N. Osborne, 2011. 'Neoliberalism, Mineral Development and Indigenous People: A Framework for Analysis.' Australian Geographer 42: 309-323. doi.org/10.1080/00049182.2011.595890

Kemp, D. and J.R. Owen, 2018. 'The Industrial Ethic, Corporate Refusal and the Demise of the Social Function in Mining.' Sustainable Development 26: 491-500. doi.org/10.1002/sd.1894

Kerins, S., 2017. 'Open Cut: Speaking Truth to Power.' Land Rights NewsNorthern Edition 2017(4): 12-13.

Kerins, S. and J. Green, 2016. 'Indigenous Country in the Southwest Gulf of Carpentaria: Territories of Difference or Indifference?' In W. Sanders (ed.), Engaging Indigenous Economy: Debating Diverse Approaches. Canberra: ANU Press (Centre for Aboriginal Economic Policy Research Monograph 35). doi.org/10.22459/caepr35.04.2016.09

Lattas, A., 1987. 'Savagery and Civilisation: Towards a Genealogy of Racism.' Social Analysis 21: 39-58.

Lewis, G. and B. Scambary, 2016. 'Sacred Bodies and Ore Bodies: Conflicting Commodification of Landscape by Indigenous Peoples and Miners in Australia's Northern Territory.' In P. McGrath (ed.), The Right to Protect Sites. Canberra: Australian Institute for Aboriginal and Torres Strait Islander Studies.

MRM (McArthur River Mine), 2018. 'Overburden Management Project: Draft Environmental Impact Statement.' Submission to the Northern Territory Environment Protection Agency. Retrieved 13 October 2020 at: ntepa.nt.gov. $\mathrm{au} /$ environmental-assessments/register/mcarthur-river-mine/mcarthur-rivermine-overburden-management-project-2018/draft-environmental-impactstatement 
O'Faircheallaigh, C., 2016. Negotiations in the Indigenous World: Aboriginal Peoples and the Extractive Industry in Australia and Canada. London: Routledge. doi.org/10.4324/9781315717951

Owen, J.R. and D. Kemp, 2017. Extractive Relations: Countervailing Power and the Global Mining Industry. London: Routledge.

Peterson, N. and M. Langton, (eds), 1983. Aborigines, Land and Land Rights. Canberra: Australian Institute of Aboriginal Studies.

Roberts, T., 2009. 'The Brutal Truth: What Happened in the Gulf Country.' The Monthly, November 2009.

Sawyer, S. and T. Gomez, 2008. 'Transnational Governmentality and Resource Extraction. Indigenous Peoples, Multinational Corporations, Multilateral Institutions and the State.' Geneva: United Nations Research Institute for Social Development, Identities, Conflict and Cohesion Programme (Paper 13).

Scambary, B., 2013. My Country, Mine Country: Indigenous People, Mining and Development Contestation in Remote Australia. Canberra: ANU E Press (Centre for Aboriginal Economic Policy Research Monograph 33). doi.org/10.22459/ CAEPR33.05.2013

South Australia, 1887. 'Government Resident's Report on the Northern Territory.' Office of the Government Resident (Northern Territory). Adelaide: Government Printer.

Stacey, B., 2018. 'The Failure of Public Policy: An Anecdote about Borroloola.' Land Rights News_-Northern Edition 2018(3): 13-15.

Vanovac, N. and J. Breen, 2017. 'McArthur River Mine: Toxic Waste Rock Ongoing Problem, Security Bond Inadequate, Report Finds.' Australian Broadcasting Corporation, 21 December. Viewed 25 September 2020 at: www.abc.net.au/ news/2017-12-21/mcarthur-river-mine-toxic-waste-rock-ongoing-problemnew-report/9278922

Walker, E., 2013. 'Yirrkala Bark Petitions.' Indigenous Law Bulletin 8(7): 33.

Young, A., 2009. ““... Jealous for Our Country”' Darwin: William Forster Chambers.

- 2015. 'McArthur River Mine: The Making of an Environmental Catastrophe.' Darwin: William Forster Chambers. 
This text is taken from The Absent Presence of the State in LargeScale Resource Extraction Projects, edited by Nicholas Bainton and Emilia E. Skrzypek, published 2021 by ANU Press, The Australian National University, Canberra, Australia.

doi.org/10.22459/AP.2021.08 